had been incised two letters belonging to the early South Arabic script. This is assigned by strati. graphic evidence to approximately the latter part of the eighth century в.c. The letters are the earliest known to bo definitely datable from a scientifically controlled excavation. Dr. Nelson Glueck, director of the School, in a preliminary account of the excavations carried out in May-June, 1939 (Illus. trated London Neus of August 5) records the dis. covery of an ingenious and complicated system of flues and chnnnels in the thick and high walls of sun-dried brick of the first city, which is so con. structed as to utilize the draught of the prevailing winds from the north for the furnaces of an elaborate complex of smelting and refining plant-the largest yet discovered in the ancient Near East. 'This system would appear to havo been the governing factor in determining the site for the first city ; and so well bonded were the bricks that many of the walls still stand almost at their original height after nearly three thousand years. Among smaller finds from the third city were Egyptian amulets, of which one was a small cat, a form characteristic of the cult of the goddess Bast of Bubastis, and another was the Uzat eye of Horus.

\section{Jenner and Napoleon}

AT a recent meeting of the Section of the History of Medicine of the Royal Society of Medicine (Proc. Roy. Soc. Med., 32, 877; 1939), Dr. J. A. Nixon said that the world.wide eminence of Edward Jenner found no better illustration than his ability to secure the liberation of British prisoners from countries with which England was at war. Ono of the best known of these prisoners was the Earl of Yarmouth, the model of 'Thackeray's Marquess of Stoyno and Disraeli's Marquess of Monmouth, on behalf of whom Jenner addressed in 1803 the following appeal to the National Institute of France: "The Sciences are never at war. . . Permit mo then as a public body with whom I am connected to solicit the exertion of your interest in the liberation of Lord Yarmouth". In 1805 Jenner addressed himself directly to Napoleon requesting that two of his friends, Mr. William Thomas Williams and J)r. John Wickham, both men of scienco and literature, might return to England. According to Baron, the well-known biographer of Jenner, it was either on this or a similar occasion that Napoleon exclaimed: "Jenner! Ah, we can refuse nothing to this man." Jenner was also successful in obtaining the release of Sir George Sinclair, who had been arrested us a spy at Góttingen. J3esides helping to liberate Englishmen detained on tho Continent, Jenner issued certificates stating that travellers abroad wero known to him and wero undertaking a voyage in pursuit of science or health or other affairs entirely unconnected with the war, and were in his opinion entitled to protection and freedom.

\section{British School of Archæology at Athens, 1935-36}

Altrougn the Annual of the British School at Athens no longer provides a general view of the activities of the School and its students- information which now must be sought in a separate publication-its contents continuo to record the more important operations of its members. The volume for 1935-36 (London: Macmillan and Co., Ltd., 1939. 42s. net), however, opens with an account, very fully illustrated, by Dr. Alex. Phila. delphus, director of the National Iruseum of Athens, of the Anavysos Kouros, a remarkable example of archaic art, in fact "one of the most perfect and almost the last link in the long chain of Apollos or kouroi that have como down to us", probably. dating at about 530 в.c. This statue, which was recovered in fragments from an antiquo dealer in Paris, had been smuggled out of Greece by sea a few years ago from Anavysos, near Laurium. Of the remainder of the contents of the volume the greater part is given up to the excavation of tho cave of Trapeza on the plain of Lasithi in eastern Crete. This cavo was first discovered by Sir Arthur Fvans in 1896, who refers to it as containing objects mainly of the Hellenistic period, but also a faienco figure of Bes and fragments of gold leaf, which afterwards found a parallel in the Early Minoan jowellery at Mokhlos. Apart from mention by Tara. melli and Bosanquet, it received no attention from archaologists until 1935, when it was visitcd by members of the School. In 1936, between May 4 and 19, it was excavated by Miss Money-Coutts, Mr. and Mrs. J. D. S. Pendlebury and others. Judging from the funds, the contents of the cave originally must have been rich. Although metal was comparatively rare, gold, silver, bronze (or copper), and lead were all repre. sented. The deposits in the cave, however, had been much disturbed by treasuro hunters, and in ono spot only were they intact. It has, therefore, been possiblo to study the pottery found for the most part on stylistic evidence only, and to reconstruct the history of the cave accordingly. It would appear to have been occupied as a habitation sito in Inato Neolithic, and to have been used for communal interment from Farly Minoan II until the end of Early Minoan III.

\section{The Cyclotron and Biological and Medical Research}

Dr. G. E. Hakrisos, lecturer in physics, in the University of Birningham, has been elected to a Rockefeller Foundation fellowship in natural science which will enable him to spend a year at Berkeley University, California, studying under Profs. J. H. and E. O. Lawrence. The object of the risit is to acquire first-hand knowledge of the application of neutrons to biological and therapeutic research, in which the Profs. Lawrence have opened up a new field the exploration of which seems likely to be of first-rate importance in the treatment of disease. Berkeley University, whero Prof. Lawrence con. structed his cyclotron and has doveloped his own technique, is unique in facilities for the production of neut rons and artificinl radioactivo substances. When the large cyclotron which I'rof. Oliphant is building for research in nuclear physics in the Physics Department of the University of Birmingham is completed, this University, in which the Physics Department and new Medical School aro in closo proximity, will 